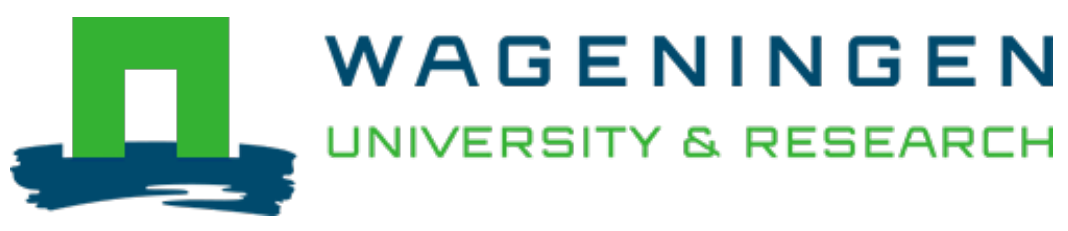

\title{
Gas production by Clostridium perfringens as a measure of the fermentability of carbohydrates and processed cereal-legume foods
}

\author{
Food Microbiology \\ Nche, P.F.; Nout, M.J.R.; Rombouts, F.M. \\ https://doi.org/10.1006/fmic.1994.1004
}

This publication is made publicly available in the institutional repository of Wageningen University and Research, under the terms of article $25 \mathrm{fa}$ of the Dutch Copyright Act, also known as the Amendment Taverne. This has been done with explicit consent by the author.

Article 25 fa states that the author of a short scientific work funded either wholly or partially by Dutch public funds is entitled to make that work publicly available for no consideration following a reasonable period of time after the work was first published, provided that clear reference is made to the source of the first publication of the work.

This publication is distributed under The Association of Universities in the Netherlands (VSNU) 'Article $25 \mathrm{fa}$ implementation' project. In this project research outputs of researchers employed by Dutch Universities that comply with the legal requirements of Article $25 \mathrm{fa}$ of the Dutch Copyright Act are distributed online and free of cost or other barriers in institutional repositories. Research outputs are distributed six months after their first online publication in the original published version and with proper attribution to the source of the original publication.

You are permitted to download and use the publication for personal purposes. All rights remain with the author(s) and / or copyright owner(s) of this work. Any use of the publication or parts of it other than authorised under article $25 \mathrm{fa}$ of the Dutch Copyright act is prohibited. Wageningen University \& Research and the author(s) of this publication shall not be held responsible or liable for any damages resulting from your (re)use of this publication.

For questions regarding the public availability of this publication please contact openscience.library@wur.nl 


\title{
Gas production by Clostridium perfringens as a measure of the fermentability of carbohydrates and processed cereal-legume foods
}

\author{
P. F. Nche, M. J. R. Nout* and F. M. Rombouts \\ Department of Food Science, Agricultural University, Bomenweg 2, \\ 6703 HD, Wageningen, The Netherlands
}

Received 11 May 1993

A new and improved method was developed for the in vitro measurement of gas produced by Clostridium perfringens, in an attempt to determine the fermentability of pure carbohydrates, processed legumes and cereal-legume mixtures. The bacterial strain, inoculum and substrate concentrations and type of carbohydrate all proved to be important factors affecting in vitro gas production by Clostridium perfringens. Increasing glucose concentrations resulted in increased gas production, but only up to $2 \%$, above which it became inhibitive. A 10-fold dilution of the active inoculum reduced the rate of gas production, whilst a 50-fold dilution produced no gas in 24 h. Strain NCTC 8239 was able to ferment a wide range of carbohydrates, with the exception of xylose. Arabinose, ribose and raffinose were, however, only moderately fermented. Native starch was also poorly fermented but, after heating, was fermented with vigorous gas production. Cooked, lactic-fermented cereal-legume composite doughs produced less gas compared to cooked non-fermented doughs. Soaking resulted in decreased fermentability of cowpea and pigeon pea, but the opposite effect was observed with soaked mungbean and soya bean. Fungal fermentation (with Rhizopus oligosporus) into tempe also had varying effects on fermentability, depending on the legume. Fungal-fermented cowpea, groundnut and pigeon pea produced more gas than similarly treated mungbean and soya bean. Steaming these products again had contrasting effects, with cowpea and pigeon pea showing reduced fermentability whilst the fermentability of mungbean and soya bean increased.

\section{Introduction}

The large scale consumption of legumes is often hindered by their poor digestibility, a consequence of which is the induction of flatus in both humans and animals (Hellendoorn 1969, Reddy et al. 1980, Kennedy et al. 1985). Legumes contain high levels of indigestible oligosaccharides ( $\alpha$-galactosides) of the raffinose family, unavailable starch and other carbohydrate fractions (Hellen-

*Corresponding author.

$0740-0020 / 94 / 010021+09 \$ 08.00 / 0$ doorn 1969, Murphy et al. 1972, Fleming 1981, Kennedy et al. 1985). These carbohydrates escape digestion in the upper gut and end up in the colon where they could be fermented by colon microflora to produce volatile fatty acids (Englyst and Macfarlane 1986, Macfarlane and Englyst 1986, Kikuchi and Sakata 1992) and gas which results in flatus (Richards et al. 1968, Rackis et al. 1970, Speck et al. 1970, Savitri et al. 1986).

Clostridium perfringens is one of the many saccharolytic bacteria (Rockland

(C) 1994 Academic Press Limited 
et al. 1969, Cummings and Macfarlane 1991) that occur in the colon microflora and contribute to the fermentation of sugars and other carbohydrates reaching the colon. This bacterium has, therefore, been used in in vitro methods to determine the fermentability of legumes and legume foods (Rockland et al. 1969, El Faki et al. 1983, Savitri et al. 1986, Nowak and Steinkraus 1988). Most of the in vitro methods reported involve the measurement of gas released from the fermentation of either pure sugars in defined media, or food homogenates inoculated with $\mathrm{Cl}$. perfringens. In these methods gas measurement usually involves the use of graduated syringes (El Faki et al. 1983, Savitri et al. 1986, Nowak and Steinkraus 1988), but inverted $10 \times 75 \mathrm{~mm}$ borosilicate glass test tubes (Rockland et al. 1969), head space pressure (Beuvink and Spoelstra 1992) and horizontal pipettes (Kikuchi and Sakata 1992) have also been used. These methods vary in accuracy and reproducibility, hence the large variability in reported results.

This study was aimed at carrying out comparative determinations of the fermentability of legume food samples as influenced by process conditions such as soaking, fermentation and cooking. To this effect, the sensitivity and reproducibility of the syringe method was evaluated. A new sensitive U-tube system for measuring gas production was developed, and test conditions were standardized. Using several strains of $\mathrm{Cl}$. perfringens, a range of carbohydrates, cereal and legume foods at different processing stages were tested for fermentability in an attempt to establish their flatulence potential after processing.

\section{Materials and Methods}

Maize (Zea mays) and the legumes cowpea (Vigna unguiculata), pigeon pea (Cajanus

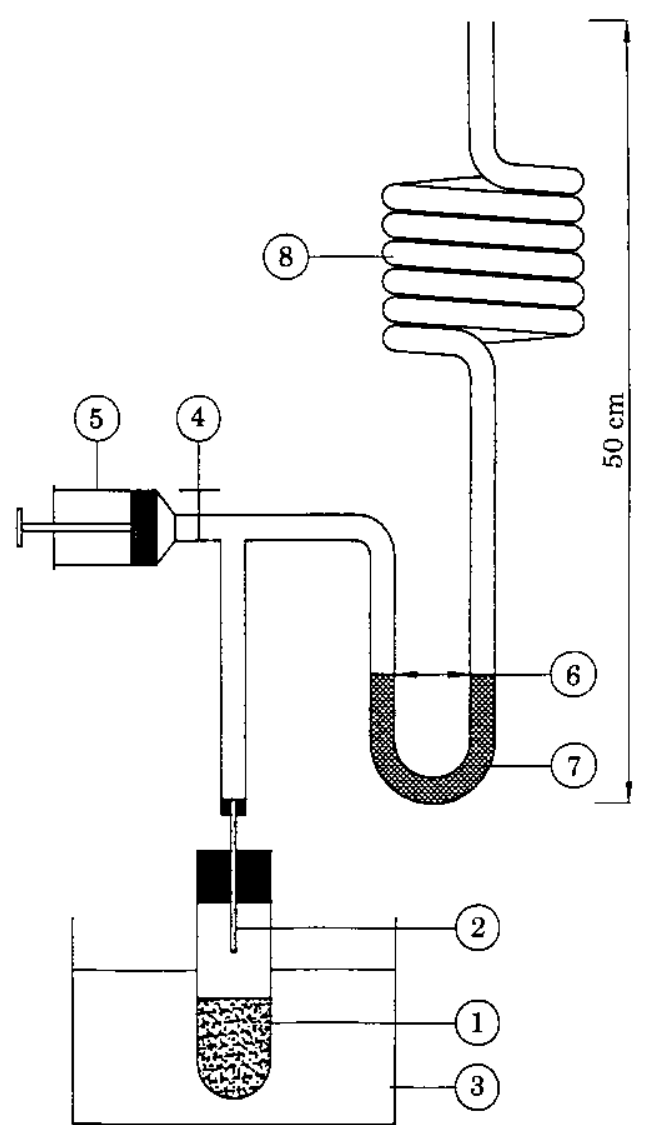

Fig. 1. Pressure-free U-tube device for gas measurement. (1) Culture vessel with known weight of culture medium (about $10 \mathrm{ml}$ ); (2) hypodermic needle linking culture vessel with U-tube; (3) thermostat controlled waterbath; (4) valve; (5) detachable gas-tight syringe (10 ml Hamilton $1010 \mathrm{~T} 11)$; (6) reference mark; (7) U-tube liquid (saturated $\mathrm{NaCl}$ solution, pH 1); (8) spiral glass capillary tube (inner diameter $=3 \mathrm{~mm}$; length $=50 \mathrm{~cm}$ ).

cajan), soya bean (Glycine max), mungbean (Vigna radiata) and groundnuts (Arachis hypogaea) were obtained from GranoDrente, Meeuwen, The Netherlands. Processed samples were freeze-dried and all samples were milled in a hammer mill (Fritsch Pulverisette, Type 14.702, Marius Instruments, Utrecht, The Netherlands) to pass through a $0.5 \mathrm{~mm}$ sieve before being tested for fermentability. The test strains were Clostridium perfringens 83V70-2, 83.42.1, 84.1.1 and NCTC 8239, obtained from the National Institute of Public Health 
and Environmental Hygiene (RIVM), Bilthoven, The Netherlands. With the exception of maize starch and ribose (Sigma Chemical Co. St Louis, USA), all other carbohydrates used were obtained from Merck (E. Merck, Darmstadt, Germany).

\section{Measurement of gas production}

(I) Syringe method. An active inoculum of $\mathrm{Cl}$. perfringens was obtained from a $24 \mathrm{~h}$ preculture at $37^{\circ} \mathrm{C}$ in thioglycollate medium U.S.P. (Oxoid CM173). A $1 \mathrm{ml}$ sample of this pre-culture was used to inoculate $20 \mathrm{ml}$ of sugar free thioglycollate medium (per litre: $5.0 \mathrm{~g}$ yeast extract, $15.0 \mathrm{~g}$ tryptone, $0.5 \mathrm{~g}$ sodium thioglycollate, $2.5 \mathrm{~g} \mathrm{NaCl}, 0.5 \mathrm{~g} \mathrm{~L}$ cystine, $0.5 \mathrm{~g}$ agar No. $1, \mathrm{pH} 7.1$ ) to which had been added the appropriate concentration of pure carbohydrate or $2 \% \mathrm{w} / \mathrm{w}$ freezedried, processed cereal-legume mix to be tested. Five $\mathrm{ml}$ each of this culture suspension were then drawn into pre-weighed graduated $20 \mathrm{ml}$ sterile plastipak syringes (Becton Dickinson, Dun Laoghaire, Co. Dublin, Ireland). After recording the exact weight of culture in the syringe, its hypodermic needle was pushed into a rubber bung to ensure hermetic closure. The syringes were then placed in a $37^{\circ} \mathrm{C}$ water bath such that the portion containing the culture medium was submerged. Unless otherwise stated, triplicate syringes were used. The volume of gas released was measured by following the movement of the plunger in the syringe. Readings were taken at regular time intervals.

(2) The pressure-free U-tube (PFUT) method. Figure 1 illustrates the experimental device (pressure-free U-tube, PFUT) which we developed to measure periodically the volume of gas produced. A volume of approximately $10 \mathrm{ml}$ of freshly inoculated liquid medium is introduced into a sterile preweighed tube (1). The weight of the culture is recorded to enable expression of gas production per unit weight of substrate. With valve (4) opened, the tube is connected to the U-tube system via a rubber bung equipped with a hypodermic needle (2). Due to the connection of the U-tube with the atmosphere, the liquid (7) levels in both arms are at equal height (6). At time 0 , valve (4) is closed and the whole set up is arranged such that the culture tube (1) suspends in a waterbath (3) maintained at $37^{\circ} \mathrm{C}$ by a thermostat heater (Haake D1, Karlsruhe, Germany). During incubation, pressure exerted by the gas released forces the liquid (7) into the spiralized arm of the U-tube. The spiral is meant to increase capacity without making the equipment cumbersome. At regular intervals, a $10 \mathrm{ml}$ graduated gastight syringe (5) is connected to valve (4), the valve is opened and the gas produced is drawn up into the syringe until the liquid (7) reaches its original level (6). The valve is closed, the syringe removed and the amount of gas produced is read from the position of the plunger in the syringe.

\section{Results and Discussion}

Figure 2 shows gas production using the syringe and U-tube methods. The syringe method gave highly variable values due to friction between plunger and syringe, and this is evident in the volume displacements of the syringe

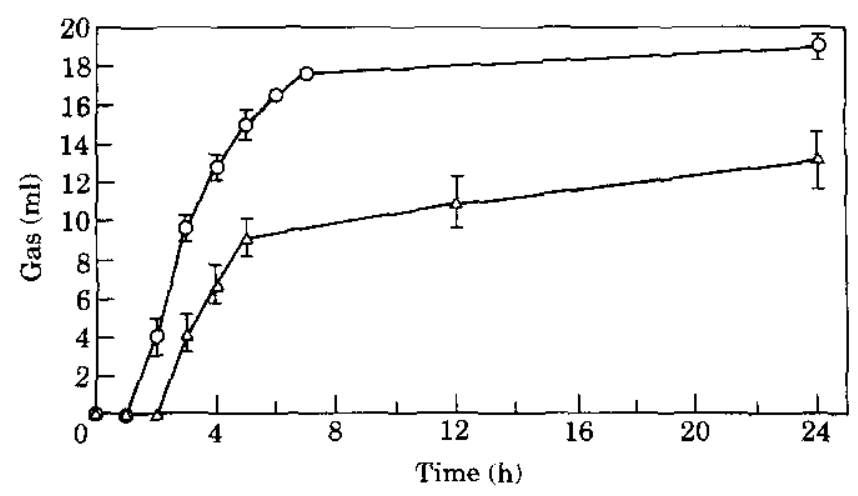

Fig. 2. Gas production (ml) by $\mathrm{Cl}$. perfringens strain NCTC 8239 in $10 \mathrm{ml}$ thioglycollate broth with $2 \%$ glucose by syringe $(\triangle)$ and pressure-free $U$-tube $(O)$ methods. (Bars indicate s.d.) 
Table 1. Effect of glucose concentration on gas production by $\mathrm{Cl}$. perfringens.

\begin{tabular}{lrr}
\hline & \multicolumn{2}{c}{ Gas produced $(\mathrm{ml})^{\mathrm{a}}$} \\
\cline { 2 - 3 } Glucose $(\%)$ & \multicolumn{1}{c}{$\begin{array}{c}\text { Strain } \\
83 \mathrm{~V} 70-2\end{array}$} & $\begin{array}{c}\text { Strain } \\
\text { NCTC 8239 }\end{array}$ \\
\hline 0.0 & $0.00 \pm 0.00^{\mathrm{b}}$ & $0.00 \pm 0.00$ \\
0.5 & $8 \cdot 83 \pm 0.85$ & $12.98 \pm 1.89$ \\
1.0 & $12.00 \pm 0.82$ & $15 \cdot 17 \pm 0.62$ \\
1.5 & $13 \cdot 17 \pm 1.17$ & $13.53 \pm 0.29$ \\
2.0 & $11.50 \pm 1.50$ & $17.58 \pm 0.51$ \\
2.5 & $9.35 \pm 0.78$ & $12.58 \pm 0.31$ \\
3.0 & $6.77 \pm 0.92$ & $12.53 \pm 0.21$ \\
\hline
\end{tabular}

arotal gas produced in $10 \mathrm{ml}$ culture after $24 \mathrm{~h}$ incubation at $37^{\circ} \mathrm{C}$.

${ }^{\mathrm{b}}$ Mean \pm s.d.; $n=3$.

plunger which were considerably less than values recorded in the U-tube. A $2 \mathrm{~h}$ delay was often required before any movement of the plunger could be recorded. The sensitivity of the U-tube is shown by the early initial recording of gas production and the higher values obtained. Reduced friction in the U-tube resulted in better reproducibility as shown by lower standard deviation in the recorded values. In addition, the absence of overpressure in the system limits the amount of $\mathrm{CO}_{2}$ dissolving in the culture medium. Compared with the pressure-free system described by Kikuchi and Sakata (1992), there is no need for graduated pipettes in which to collect the gas. We also found that the larger internal diameter of graduated pipettes resulted in easy collapse of the liquid meniscus.

The effect of substrate concentration (Table 1) on the total gas produced was investigated in sugar-free thioglycollate medium to which different glucose concentrations had been added. The two strains of $C l$. perfringens used showed significant $(P \leq 0.05)$ inhibition at glucose concentrations $>2 \%$. In order to standardize experimental conditions and to avoid unwanted inhibitory effects, the level of carbohydrate was limited to $2 \%$ in further experiments.

Table 2 shows that the rate and amount of gas produced were very much influenced by the initial cell density of the inoculum. A 10 fold dilution of inoculum resulted initially in a slower rate of gas production, although this had no effect on the total gas produced after $24 \mathrm{~h}$. Further dilution by 50 fold resulted in no gas production within the $24 \mathrm{~h}$ of measurement (result not shown). Although not tested by us, inoculation at levels exceeding $10^{7} \mathrm{cfu} \mathrm{ml}^{-1}$ could be expected to increase the rate and possibly the amount of gas production. This would, however, require additional preparatory work with centrifugation and re-suspension, whilst avoiding any unwanted contamination. Other authors (Nowak and Steinkraus 1988) have also reported a good positive correlation between gas production and cell density.

Table 2. Effect of inoculum size on growth and gas production by $\mathrm{Cl}$. perfringens strain NCTC 8239 in $10 \mathrm{ml}$ thioglycollate broth with $2 \%$ glucose.

\begin{tabular}{|c|c|c|c|c|}
\hline \multirow{2}{*}{$\begin{array}{l}\text { Incubation } \\
\text { Time }(\mathrm{h})\end{array}$} & \multicolumn{2}{|c|}{ Undiluted inoculum ${ }^{\mathrm{a}}$} & \multicolumn{2}{|c|}{10 fold dilution } \\
\hline & $\log _{10} \mathrm{cfu} \mathrm{ml} l^{-1}$ & Gas $(\mathrm{ml})^{\mathrm{b}}$ & $\log _{10} \mathrm{cfu} \mathrm{ml} l^{-1}$ & $\operatorname{Gas}(\mathrm{ml})$ \\
\hline 0 & 7.02 & $0 \cdot 00 \pm 0.00$ & $6 \cdot 15$ & $0.00 \pm 0.00$ \\
\hline 3 & $7 \cdot 88$ & $1.63 \pm 0.13$ & $6 \cdot 25$ & $0.33 \pm 0.08$ \\
\hline 6 & 8.95 & $5.75 \pm 0.25$ & $8 \cdot 14$ & $3.70 \pm 0.21$ \\
\hline 24 & 7.90 & $17.63 \pm 0.63$ & 7.91 & $21 \cdot 13 \pm 1.47$ \\
\hline
\end{tabular}

a Pre-cultured in $10 \% \mathrm{v} / \mathrm{v}$ Brain Heart Infusion medium for $24 \mathrm{~h}$ at $37^{\circ} \mathrm{C}$.

${ }^{\mathrm{b}}$ Average \pm s.d.; $n=3$. 
Table 3. Growth and gas production by $C l$. perfringens strain NCTC 8239 incubated for $24 \mathrm{~h}$ at $37^{\circ} \mathrm{C}$ on $2 \%$ carbohydrate in $10 \mathrm{ml}$ thioglycollate broth (inoculum pre-cultured in thioglycollate broth with $0.5 \%$ glucose).

\begin{tabular}{|c|c|c|c|c|}
\hline \multirow[b]{2}{*}{$\begin{array}{l}\text { Carbo- } \\
\text { hydrate }\end{array}$} & \multicolumn{2}{|c|}{ Growth } & \multirow[b]{2}{*}{$\begin{array}{l}\text { Gas } \\
(\mathrm{ml})^{\mathrm{a}}\end{array}$} & \multirow[b]{2}{*}{ s.d. ${ }^{b}$} \\
\hline & $\mathrm{OD}^{\mathrm{c}}$ & $\underset{\log _{10} \mathrm{cfu}}{\mathrm{ml}^{-1}}$ & & \\
\hline None & 0.64 & 8.04 & 0.00 & 0.00 \\
\hline Arabinose & 1.02 & $\mathrm{ND}^{d}$ & $3 \cdot 40$ & 0.20 \\
\hline Fructose & 3.39 & $8 \cdot 18$ & $20 \cdot 00$ & 0.30 \\
\hline Galactose & $3 \cdot 20$ & $8 \cdot 18$ & $16 \cdot 90$ & $0 \cdot 10$ \\
\hline Glucose & 3.67 & 7.90 & 22.80 & 1.70 \\
\hline Maltose & 4.25 & 7.87 & $23 \cdot 40$ & 0.40 \\
\hline Mannose & $\mathrm{ND}$ & $\mathrm{ND}$ & $19 \cdot 20$ & 1.10 \\
\hline Raffinose & 1.23 & 7.88 & $8 \cdot 50$ & 0.10 \\
\hline Ribose & 1.46 & ND & $10 \cdot 00$ & 0.10 \\
\hline Starch (nati & ND & ND & $4 \cdot 10$ & $0 \cdot 10$ \\
\hline Starch $\left(\right.$ heated $\left.^{\mathrm{e}}\right)$ & ND & 8.63 & $24 \cdot 60$ & 1.50 \\
\hline Sucrose & $4 \cdot 16$ & ND & $16 \cdot 80$ & 1.70 \\
\hline Xylose & ND & ND & 0.00 & $0 \cdot 00$ \\
\hline
\end{tabular}

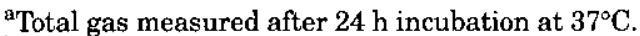

bs.d. $(n=3)$.

${ }^{c}$ Optical density at $660 \mathrm{~nm}$, measured as diluted in the range $<1.0$ and multiplied by respective dilution factors.

${ }^{\mathrm{d}}$ Not determined.

${ }^{\text {e}}$ Heated for $10 \mathrm{~min}$ at $90^{\circ} \mathrm{C}$.

The ability of $\mathrm{Cl}$. perfringens strain NCTC 8239 to ferment a wide range of carbohydrates is presented in Table 3 .
With the exception of xylose, all other carbohydrates tested were fermented. The pentoses arabinose and ribose and the trisaccharide raffinose were, however, fermented with only moderate gas production. Native starch was poorly fermented, probably because of its inaccessibility. However, after heating, the then gelatinized starch caused the highest gas production recorded. These results fall in line with previous reports (Nowak and Steinkraus 1988) showing that gas production by $\mathrm{Cl}$. perfringens 546 varied with the carbohydrate present in the culture medium. This variation could be related to the ability of the bacteria to adapt to the carbohydrate tested, or in the case of the pentoses, to the different pattern of fermentation products formed. Our tests to the effect of induction showed that $\mathrm{Cl}$. perfringens pre-cultured on glucose-containing thioglycollate medium produced relatively small amounts of gas on raffinose compared with glucose. However, if precultured on raffinose, gas production by strains 83.42.1 and NCTC 8239 on raffinose was doubled (Table 4). Strain 84.1.1, on the other hand, responded differently by producing very little gas on raffinose irrespective of pre-cultivation

Table 4. Effect of pre-culturing conditions on gas production by $\mathrm{Cl}$. perfringens in $10 \mathrm{ml}$ thioglycollate broth containing glucose or raffinose.

\begin{tabular}{|c|c|c|}
\hline $\begin{array}{l}\text { Pre-cultured }{ }^{\mathrm{a}} \text { in } \\
\text { thioglycollate with: }\end{array}$ & $\begin{array}{c}\text { Gas }^{\mathrm{b}} \text { production (wi } \\
2 \% \text { glucose }\end{array}$ & $\begin{array}{l}\text { ate broth containing } \\
2 \% \text { raffinose }\end{array}$ \\
\hline \multicolumn{3}{|l|}{$0.5 \%$ glucose } \\
\hline Strain 83.42 .1 & $13.50(0.60)$ & $5 \cdot 30(0 \cdot 30)$ \\
\hline Strain NCTC 8239 & $22.80(1.70)$ & $8.50(0 \cdot 10)$ \\
\hline Strain 84.1.1 & $20.60(0.10)$ & $1.00(0.10)$ \\
\hline \multicolumn{3}{|l|}{$2 \%$ raffinose } \\
\hline Strain 83.42 .1 & $17.70(0.39)$ & $9 \cdot 10(0 \cdot 10)$ \\
\hline Strain NCTC 8239 & $18.80(0.10)$ & $20.10(0.10)$ \\
\hline Strain 84.1.1 & $14.17(0.92)$ & $0.30(0.10)$ \\
\hline
\end{tabular}

${ }^{\mathrm{a}} 24 \mathrm{~h}$ at $37^{\circ} \mathrm{C}$.

b Total gas produced after $24 \mathrm{~h}$ expressed in $\mathrm{ml}$.

$c_{\text {s.d. }}(n=3)$. 
Table 5. Fermentability of processed cereal-legume mixtures by $\mathrm{Cl}$. perfringens strain 83V70-2. (Total gas production in $24 \mathrm{~h}$ at $37^{\circ} \mathrm{C}$, expressed as $\mathrm{ml} \mathrm{g}^{-1} \mathrm{dry}$ matter.)

\begin{tabular}{lccccc}
\hline $\begin{array}{l}\text { Processing } \\
\text { stage }\end{array}$ & $\begin{array}{c}\text { MSC } \\
(30: 30: 40)^{\mathrm{a}}\end{array}$ & $\begin{array}{c}\text { MSG } \\
(30: 35: 35)\end{array}$ & $\begin{array}{c}\text { MSM } \\
(30: 30: 40)\end{array}$ & $\begin{array}{c}\text { MSP } \\
(30: 30: 40)\end{array}$ & $\begin{array}{c}\text { MSS } \\
(35: 35: 30)\end{array}$ \\
\hline Raw & 40 & 55 & 50 & 35 & 30 \\
Fermented $^{\mathrm{b}}$ & 15 & 10 & 10 & 10 & 15 \\
Fermented + cooked $^{\mathrm{c}}$ & 30 & 0 & 35 & 25 & 45 \\
Non-fermented + cooked & 55 & 20 & 60 & 35 & 0 \\
\hline
\end{tabular}

${ }^{a}$ Weight ratio on dry matter basis.

${ }^{b}$ Accelerated natural lactic fermentation at $30^{\circ} \mathrm{C}$ for $24 \mathrm{~h}$.

${ }^{\mathrm{c}}$ Cooked at $100^{\circ} \mathrm{C}$ for $5 \mathrm{~min}$.

MSC, maize/sorghum/cowpea; MSG, maize/sorghum/groundnut; MSM, maize/sorghum/mungbean; MSP, maize/sorghum/pigeon pea; MSS, maize/sorghum/soya bean.

conditions. An adaptive response to different carbohydrates by Bacteroides ovatus was reported by Macfarlane et al. (1990). These authors showed that $B$. ovatus was able to synthesize enzymes specific to the carbohydrate contained in the culture medium. The response of the $\mathrm{Cl}$. perfringens strains 83.42 .1 and NCTC 8239 is probably an indication of their ability to synthesize the enzymes required to degrade the various carbohydrates tested.

Growth of the bacteria was determined by both plate counts and spectrophotometric measurements of optical density (OD) at $660 \mathrm{~nm}$, using a DU Series 60 spectrophotometer (Beckman Instruments, Mijdrecht, The Netherlands). An interesting observation to note here is that, whereas plate counts of colony forming units, after $24 \mathrm{~h}$ incubation at $37^{\circ} \mathrm{C}$, were of the same order of magnitude, regardless of the carbohydrate tested (Table 3 ), some carbohydrates, e.g. glucose and maltose produced much more biomass (measured as OD) compared to raffinose or the sugar-free control. This indicates that a high turnover of cells occurs, and that the difference in oD values represents already dead cells which are, nonetheless, detected spectrophotomet- rically. High oD values also correlate much better with total gas production (Pearson's $r^{2}=0.88$ ) than do plate counts $\left(r^{2}=0.09\right)$.

In addition to pure carbohydrates, several food samples were tested for their fermentability following different process treatments. Table 5 shows results obtained with raw and processed cereal-legume mixtures. As can be expected from earlier results with pure carbohydrates (Table 3), gas production from food samples reflected the availability of fermentable carbohydrates. Freshly milled raw composite flours containing maize, sorghum and several legumes contain sufficient fermentable carbohydrates such as mono- and disaccharides. After only natural lactic fermentation, the fermentability for $\mathrm{Cl}$. perfringens is considerably lower since easily fermentable mono- and disaccharides have already been consumed by lactic acid bacteria. However, the starch fraction is still in native form, not having been heated or degraded and lactic acid bacteria are very poor starch degraders. Cooking the fermented dough, however, results in starch gelatinization hence increased fermentability of starch (compare Table 3) with the exception of groundnut mix. With the exception of 
Table 6. Effect of tempe manufacturing process on the fermentability of legumes by $C l$. perfringens strain $83 \mathrm{V70-2}$. (Total gas production in $24 \mathrm{~h}$ at $37^{\circ} \mathrm{C}$, expressed as $\mathrm{ml} \mathrm{g}^{-1}$ dry matter.)

\begin{tabular}{|c|c|c|c|c|c|}
\hline Processing stage & Cowpea & Groundnut & Mungbean & Pigeon pea & Soya bean \\
\hline Raw & 40 & 0 & 20 & 45 & 10 \\
\hline Soaked + cooked ${ }^{a}$ & 15 & 0 & 40 & 0 & 25 \\
\hline Fermented $^{b}$ & 40 & 10 & 0 & 110 & 0 \\
\hline Steamed ${ }^{c}$ & 20 & 10 & 50 & 30 & 5 \\
\hline
\end{tabular}

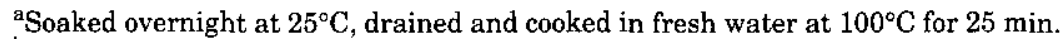

${ }^{b}$ Fermented with Rhizopus oligosporus at $30^{\circ} \mathrm{C}$ for $44 \mathrm{~h}$.

${ }^{c}$ Fresh tempe steamed for $15 \mathrm{~min}$.

soya bean mix, less gas was produced from cooked fermented doughs compared to cooked non-fermented flours which still contained higher levels of mono- and disaccharides (data not shown).

Table 6 summarizes the extent of fermentability of legumes when processed into tempe. Except for groundnuts, raw legumes contain readily fermentable carbohydrates. Soaking, followed by cooking had varying effects on fermentability. In cowpea and pigeon pea, fermentability decreased, possibly due to loss of fermentable carbohydrates by leaching. Soaking and cooking have also been reported to reduce the oligosaccharide content of some legumes, resulting in a decrease in flatulence (Silva and Braga 1982, Jood et al. 1985). Mungbean and soya bean, on the other hand, showed increased fermentability. This could be attributed to better availability of polysaccharides (i.e. starch in mungbean) or to inactivation of antimicrobial factors such as were described by Nowak and Steinkraus (1988), in soya beans.

Fungal fermentation had different effects depending on the legume used. Increases in fermentability were found in cowpea, groundnut and pigeon pea. Such increases might have been caused by improved accessibility of fermentable substrate, due to the enzymes produced by Rhizopus oligosporus (Sarrette et al.
1992). Fungal fermentation of mungbean and soya bean, on the other hand, resulted in reduced fermentability. Presumably here, any fermentable carbohydrates liberated have been assimilated during the fermentation (as in Table 5). In addition, the formation of antimicrobial substances by $R$. oligosporus in soya bean was reported elsewhere (Wang et al. 1969, Nowak and Steinkraus 1988, Nout and Rombouts 1990). If present, such antimicrobials might have affected the gas production capacity of $\mathrm{Cl}$. perfringens. Steaming resulted in reduced fermentability of fungal-fermented cowpea and pigeon pea. These results contradict those obtained for steamed groundnut, mungbean and soya bean which all showed increased fermentability. A similar observation for soya bean (Nowak and Steinkraus 1988) has been attributed to the inactivation, by steam, of the factors inhibitory to $\mathrm{Cl}$. perfringens, thereby allowing for the bacteria to grow and produce gas.

In conclusion, our results clearly point out potential difficulties that could be encountered when trying to estimate the fermentability of food products by in vitro methods. Several important parameters such as the sensitivity of the equipment used, the type and pre-culture conditions of the bacteria used cannot be overlooked. It must also be made clear that this simple 
approach which has also been followed by several other authors (Rockland et al. 1969, El Faki et al. 1983, Savitri et al. 1986, Nowak and Steinkraus 1988, Kikuchi and Sakata 1992) cannot represent a model of digestion and flatulence in humans. $\mathrm{Cl}$. perfringens is, of course, only one of a wide range of different bacteria occurring in the human colon and which ferment carbohydrates reaching the colon. Also, as we have shown, many mono- and disaccharides cause more gas production than indigestible oligosaccharides. In the human digestive tract, accessible starch is broken down to mono- and disaccharides which are ab- sorbed in the upper gut. In vitro models of digestibility and fermentability, therefore, need to take this aspect into account. We are currently developing a simple system to this effect.

\section{Acknowledgements}

We thank A. Tewarie, C. Maessen and F. Erdelmann for their technical contribution. Financial support from the European Community (Contract No. TS2-0267-UK, "The evaluation and improvement of traditional fermented cereals and legumes in Ghana') is gratefully acknowledged.

\section{References}

Beuvink, J. M. W. and Spoelstra, S. F. (1992) Interactions between substrate, fermentation and end-products, buffering systems and gas production upon fermentation of different carbohydrates by rumen microorganisms in vitro. Appl. Microbiol. Biotech. 37, 505-509.

Cummings, J. H. and Macfarlane, G. T. (1991) The control of bacterial fermentation in the human colon. J. Appl. Bacteriol. 70, 443-459.

El Faki, H. A., Bhavanishangar, T. N., Tharanathan, R. N. and Desikachar, H. S. R. (1983) Flatus effect of chickpea (Cicer arietinum), Cowpea (Vigna sinensis) and horse gram (Dolichos biflorus) and their isolated carbohydrate fractions. Nutr. Rep. Int. 27, 922-930.

Englyst, H. N. and Macfarlane, G. T. (1986) Breakdown of resistant and readily digestible starch by human gut bacteria. J. Sci. Food Agric. 37, 699-706.

Fleming, S. E. (1981) A study of relationships between flatus potential and carbohydrate distribution in legume seeds. J. Food Sci. 46, 794-798.

Hellendoorn, E. W. (1969) Intestinal effects following ingestion of beans. Food Technol. 33, 268-271.

Jood, S., Mehta, U., Singh, R. and Bhat, C. M. (1985) Effect of processing on flatus-producing factors in legumes. J. Agric. Food Chem. 33, 268-271.

Kennedy, I. R., Mwandemele, O. D. and McWhirter, K. S. (1985) Estimation of sucrose, raffinose and stachyose in soybean seeds. Food Chem. 17, 85-93.

Kikuchi, H. and Sakata, T. (1992) Qualitative and quantitative estimation of soluble indigestible polysaccharides as substrate for hindgut fermentation by mini-scale batch culture. J. Nutr. Sci. Vitaminol. 38, 287-296.

Macfarlane, G. T. and Englyst, H. N. (1986) Starch utilization by human large intestinal microflora. J. Appl. Bacteriol. 60, 195-201.

Macfarlane, G. T., Hay, S., Macfarlane, S. and Gibson, G. R. (1990) Effect of different carbohydrates on growth, polysaccharidase and glucosidase production by Bacteriodes ovatus in batch and continuous culture. J. Appl. Bacteriol. 68, 179-187.

Murphy, E. L., Horsley, Y. H. and Burr, H. K. (1972) Fractionation of dry bean extracts which increase carbon dioxide egestion in human flatus. J. Agric. Food Chem. 20, 813-817.

Nout, M. J. R. and Rombouts, F. M. (1990) Recent developments in tempe research. J. Appl. Bacteriol. 69, 609-633.

Nowak, J. and Steinkraus, K. H. (1988) Effect of tempeh fermentation of peas on their potential flatulence productivity as measured by gas production and growth of Clostridium perfringens. Nutr. Rep. Int. 38, 1163-1171. 
Rackis, J. J., Sessa, D. J., Steggerda, F. R., Shimisu, T., Anderson, J. and Pearl, S. L. (1970) Soya bean factors relating to gas production by intestinal bacteria. J. Food Sci., 35, 634-639.

Reddy, N. R., Salunkhe, D. K. and Sharma, R. P. (1980) Flatulence in rats following ingestion of cooked and germinated black gram and rice blend. J. Food Sci. 45, 1161-1164.

Richards, E. A., Steggerda, F. R. and Murata, A. (1968) Relation of bean substrates and certain intestinal bacteria to gas production in dog. Gastroenterology 55, 502-509.

Rockland, L. B., Gardiner, B. L. and Pieczarka, D. (1969) Stimulation of gas production and growth of Clostridium perfringens type A (No. 3624) by legumes. J. Food Sci. 34, 411-414.

Sarrette, M., Nout, M. J. R., Gervais, P. and Rombouts, F. M. (1992) Effects of water activity on production and activity of Rhizopus oligosporus polysaccharidases. App. Microbiol. Biotech. 37, 420-425.

Savitri, A., Bhavanishankar, T. N. and Desikachar, H. S. R. (1986) Effect of spices on in vitro gas production by Clostridium perfringens. Food Microbiol. 3, 195-199.

Silva, H. C. and Braga, G. L. (1982) Effect of soaking and cooking on the oligosaccharide content of dry beans (Phaseolus vulgaris, L). J. Food Sci. 47, 924-925.

Speck, R. S., Calloway, D. H. and Hadley, W. K. (1970) Human faecal flora under controlled diet intake. Am. J. Clin. Nutr. 23, 1488-1494.

Wang, H. L., Ruttle, D. I. and Hesseltine, C. W. (1969) Antibacterial compound from a soybean product fermented by Rhizopus oligosporus. Proc. Soc. Exp. Biol. Med. 131, 579-583. 